\title{
Indeks Maya dan Indeks Entomologi Vektor Demam Berdarah Dengue di Kabupaten Mamuju Tengah, Sulawesi Barat
}

\section{Maya Index and Entomology Index of Dengue Hemorrhagic Fever Vector in Central Mamuju Regency, West Sulawesi}

\author{
Murni*, Nelfita, Risti, Hasrida Mustafa, Malonda Maksud \\ Balai Penelitian dan Pengembangan Kesehatan Donggala, Badan Litbang Kesehatan, \\ Kementerian Kesehatan RI \\ Jalan Masitudju No.58 Labuan Panimba, Kecamatan Labuan, Donggala, Sulawesi Tengah, Indonesia \\ *E_mail: murni_amiruddin@yahoo.co.id
}

Received date: 15-06-2015, Revised date: 24-11-2020, Accepted date: 25-11-2020

\begin{abstract}
ABSTRAK
Keberadaan kontainer sebagai habitat potensial bagi perkembangbiakan nyamuk di tengah masyarakat dapat mempengaruhi kepadatan populasi Aedes. Indeks maya merupakan indikator untuk mengukur jumlah kontainer yang dapat menjadi tempat nyamuk berkembang biak. Penelitian ini bertujuan untuk mengetahui gambaran indeks maya dan indeks entomologi di Kabupaten Mamuju Tengah, Provinsi Sulawesi Barat. Penelitian ini merupakan penelitian observasional yang dilakukan pada tahun 2015 di tiga Kecamatan (Topoyo, Tappilina, dan Karossa) Kabupaten Mamuju Tengah. Pengumpulan data melalui wawancara terstruktur terhadap kepala rumah tangga pada 100 rumah yang dipilih secara acak dengan metode rumah terdekat dan pengukuran kepadatan larva menggunakan metode single larva. Hasil analisis indeks maya menunjukkan bahwa nilai Breeding Risk Index (BRI) untuk tiga kecamatan di Kabupaten Mamuju Tengah sebagian besar berada pada kategori sedang, sedangkan nilai Hygiene Risk Index (HRI) dan Maya Index (MI) berada pada kategori rendah. Berdasarkan indikator House Index (HI) dan Container Index (CI) menunjukkan bahwa kepadatan jentik (density figure) di Kabupaten Mamuju tengah tergolong sedang, meskipun demikian potensi terjadinya penularan DBD masih tetap ada.
\end{abstract}

Kata kunci: indeks maya, indeks entomologi, Sulawesi Barat

\begin{abstract}
The existence of containers as a potential habitat breeding places for mosquitoes in the community can affect the population density of Aedes. The maya index is an indicator to measure the number of containers that can be a breeding places for mosquitoes. This study aims to determine maya index and entomology index in Central Mamuju Regency, West Sulawesi Province. This study was an observational study conducted in 2015 in three sub-districts (Topoyo, Tappilina, and Karossa) in Central Mamuju Regency. Data collection through structured interviews with household heads in 100 randomly selected houses using the closest house method and measuring larvae density using the single larva method. The results showed that the Breeding Risk Index (BRI) for the three sub-districts in Central Mamuju Regency are mostly in the medium category, while Hygiene Risk Index (HRI) and Maya Index (MI) are in a low category. Based on House Index (HI) and Container Index (CI) indicators means Central Mamuju Regency have a moderate risk of transmission Dengue.
\end{abstract}

Keywords: maya index, entomology index, West Sulawesi 


\section{PENDAHULUAN}

Demam berdarah dengue (DBD) merupakan salah satu masalah kesehatan masyarakat yang utama di Indonesia. Jumlah penderita dan luas daerah penyebarannya semakin bertambah seiring dengan meningkatnya mobilitas dan kepadatan penduduk. Penyakit ini dapat menimbulkan kejadian luar biasa (KLB) dan bisa menyebabkan kematian dalam waktu yang singkat. ${ }^{1,2}$

DBD ditularkan oleh vektor, yaitu nyamuk Aedes aegypti dan Aedes albopictus. Kedua spesies tersebut mempunyai kapasitas vektor sehingga dapat berperan sebagai vektor. Kapasitas vektor kedua spesies ini diantaranya rentan terhadap infeksi virus dengue, mampu mereplikasi virus dengue, dan mampu memindahkan virus dengue kepada manusia. Perbedaannya, Ae. aegypti memiliki kompetensi vektor lebih tinggi karena merupakan antropofilik yang sangat kuat, memiliki habitat di pemukiman dan memiliki perilaku menggigit berkali-kali untuk melengkapi satu siklus gonotropik. Sedangkan Ae. albopictus masih memiliki sifat liar, habitatnya lebih banyak di lingkungan terbuka dan hanya menghisap darah sekali selama satu siklus gonotropik. $^{3}$

Dalam siklus hidupnya nyamuk Aedes spp. mengalami metamorfosis sempurna, yaitu: telur - jentik - kepompong - nyamuk. Kehidupan stadium telur, jentik dan kepompong terjadi di dalam air sehingga, beberapa pengendalian nyamuk Aedes spp. dilakukan dalam fase ini, seperti menaburkan larvasida (abate) dan melepaskan predator jentik. Nyamuk Ae. aegypti biasanya menyukai genangan air yang bersih dan tidak berhubungan langsung dengan tanah. Beberapa penelitian menunjukan bahwa nyamuk Aedes banyak ditemukan pada penampungan air berwadah besar, seperti bak mandi, dan drum. Hal ini terjadi karena wadah-wadah tersebut biasanya sulit untuk dibersihkan. ${ }^{4}$ Tempat perkembangbiakan yang disukai Ae. aegypti adalah genangan air yang terdapat dalam wadah (kontainer) tempat penampungan air artifisial misalnya drum, bak mandi, gentong, dan ember. Tempat penampungan air alamiah misalnya lubang pohon, daun pisang, pelepah daun keladi, lubang batu; ataupun bukan tempat penampungan air misalnya vas bunga, ban bekas, botol bekas, tempat minum burung dan sebagainya. ${ }^{5,6}$

Keberadaan kontainer sebagai habitat potensial bagi perkembangbiakan nyamuk di tengah-tengah masyarakat dapat mempengaruhi kepadatan populasi Ae. aegypti. Kedua aspek ini memiliki makna yang penting bagi program pengendalian vektor dan penyakit DBD karena hingga saat ini belum ditemukan obat bagi penyakit ini walaupun vaksin Dengue sudah diproduksi namun hingga saat ini belum diaplikasikan di Indonesia. $^{7}$

Dua kabupaten di Provinsi Sulawesi Barat termasuk dalam kategori zona merah Demam Berdarah Dengue (DBD), yakni Kabupaten Mamuju dan Pasangkayu. Status zona merah tersebut ditetapkan Kementerian Kesehatan RI sejak Januari 2019 karena tingginya penyebaran DBD di dua daerah tersebut. Data Dinas Kesehatan Mamuju mencatat sepanjang tahun 2019, terdapat 312 kasus DBD dan satu orang meninggal dunia akibat menderita demam berdarah. Empat kabupaten lainnya masuk kategori waspada, yakni Mamuju, Mamuju Tengah, Polewali Mandar, dan Majene. ${ }^{8}$

Penelitian ini bertujuan untuk memperoleh data tentang indeks maya dan indeks entomologi berupa status kepadatan vektor DBD berdasarkan nilai besar House Index (HI), Container Index (CI), dan Breteau Index (BI) sesuai dengan standar $\mathrm{WHO}$, dan Angka Bebas Jentik (ABJ) sesuai dengan standar nasional, serta menentukan kontainer dominan sebagai preferensi bertelur nyamuk di daerah endemis DBD di Kabupaten Mamuju Tengah Provinsi Sulawesi Barat. Informasi kepadatan vektor diperlukan sebagai indikator potensi penularan virus dengue, dan informasi kontainer dominan diperlukan untuk 
menentukan target utama dalam pengendalian vektor. ${ }^{9}$

\section{METODE}

Penelitian ini merupakan bagian dari penelitian multicenter Peta Kerentanan Nyamuk Aedes aegypti di Indonesia dengan lokasi studi di lima provinsi di Sulawesi dengan Surat Persetujuan Etik No. LB.02.01/5.2/KE.105/2015. Studi ini dilakukan di Kabupaten Mamuju Tengah, Provinsi Sulawesi Barat yang dilaksanakan pada Bulan Juli sampai Agustus 2015. ${ }^{10}$ Pemilihan lokasi survei berdasarkan tingkat endemisitas DBD tahun 2015. Selanjutnya dipilih RW atau dusun dengan kasus DBD tertinggi selama 3 tahun berturut-turut. Pengumpulan data dilakukan melalui wawancara terstruktur terhadap kepala rumah tangga atau yang mewakili pada minimal 100 rumah yang dipilih secara acak dengan metode rumah terdekat. ${ }^{11}$

Analisis indeks maya dan indeks entomologi digunakan untuk menggambarkan risiko penularan DBD. Kontainer dominan diidentifikasi dengan mendata jenis-jenis kontainer yang paling banyak positif jentik yang ditemukan di dalam maupun di luar rumah. Kontainer dalam hal ini dikelompokkan menjadi dua kategori yaitu kontainer terkendali (controllable container) dan kontainer bekas (disposable container). Indeks maya digunakan untuk mengidentifikasi suatu area berisiko tinggi sebagai tempat perkembangbiakan (breeding site) nyamuk Aedes spp. yang diperoleh dengan menghitung dua indikator yaitu indikator risiko perkembangbiakan/Breeding Risk Index (BRI) dan risiko kebersihan lingkungan/Hygiene Risk Index (HRI) yang masing-masing dikategorikan kedalam tiga tingkatan risiko yaitu tinggi, sedang dan rendah. Nilai BRI diperoleh dari pembagian antara jumlah Controllable Container (CC) yang ditemukan di rumah tangga dengan ratarata CC yang positif larva. Nilai HRI diperoleh dari pembagian antara jumlah Disposable Container (DC) di rumah tangga dengan ratarata DC positif larva. Indeks maya diperoleh dari hasil nilai indikator HRI dan BRI dengan membentuk tabel matriks $3 \times 3$ yang dikategorikan tinggi, sedang, dan rendah berdasarkan distribusi tertil Kategori MI tinggi jika BRI3/HRI3, BRI3/HRI2, dan BRI2/HRI3; kategori MI sedang jika BRI1/HRI3, BRI2/HRI2, dan BRI3/HRI1; kategori MI rendah jika BRI1/HRI1, BRI2/HRI1, dan BRI1/HRI. ${ }^{12}$ Kategori MI dapat dilihat pada Tabel 1.

Tabel 1. Matriks 3x3 Komponen Breeding Risk Indicator (BRI) dan Hygiene Risk Indicator (HRI) pada Indeks Maya

\begin{tabular}{|c|c|c|c|c|}
\hline & & \multicolumn{3}{|c|}{ BRI } \\
\hline & & Rendah (1) & Sedang (2) & Tinggi (3) \\
\hline \multirow{3}{*}{ HRI } & $\begin{array}{c}\text { Rendah } \\
\text { (1) }\end{array}$ & BRI1/HRI1 (rendah) & BRI2/HRI1 (rendah) & BRI3/HRI1 (sedang) \\
\hline & $\begin{array}{l}\text { Sedang } \\
\text { (2) }\end{array}$ & BRI1/HRI2 (rendah) & BRI2/HRI2 (sedang) & BRI3/HRI2 (tinggi) \\
\hline & $\begin{array}{c}\text { Tinggi } \\
(3)\end{array}$ & BRI1/HRI3 (sedang) & BRI2/HRI3 (tinggi) & BRI3/HRI3 (tinggi) \\
\hline
\end{tabular}


Pengukuran kepadatan larva menggunakan metode single larva yaitu pengambilan satu larva di setiap tempat penampungan air yang ditemukan larva untuk diidentifikasi untuk mengetahui jenis larva nyamuk. Cara Pengumpulan larva sebagai berikut: 1) Semua tempat atau bejana baik di dalam maupun di luar rumah yang dapat menjadi tempat perkembang biakan nyamuk Ae. aegypti diperiksa (secara visual) untuk mengetahui ada tidaknya larva; 2) Untuk memeriksa larva di tempat yang agak gelap atau airnya keruh digunakan senter selama 3 menit; 3) Data larva yang ditemukan di lapangan kemudian dihitung House Index (HI), Container Index (CI), Breteau Index (BI), dan Density Figure (DF). Data dianalisis secara deskriptif dengan pendekatan indikator populasi jentik DBD yang dinilai dengan metode indeks larva sebagai berikut: ${ }^{13}$

$$
\begin{gathered}
H I=\frac{\text { Jumlah Bangunan Positif }}{\text { Jumlah Bangunan di Periksa }} \times 100 \% \\
C I=\frac{\text { Jumlah Kontainer Positif }}{\text { Jumlah Kontainer di Periksa }} \times 100 \% \\
B I=\frac{\text { Jumlah Kontainer Positif }}{\text { Jumlah Rumah di Periksa }} \times 100 \% \\
A B J=\frac{\text { Jumlah Bangunan Negatif Jentik }}{\text { Jumlah Bangunan di Periksa }} \times 100 \%
\end{gathered}
$$

HASIL

\section{Jenis Kontainer}

Jenis kontainer dan kepadatan populasi larva pada tiga kecamatan di Kabupaten Mamuju Tengah disajikan pada Tabel 2. Berdasarkan hasil survei entomologi diperoleh 1119 kontainer pada rumah tangga pada tiga kecamatan di Kabupaten Mamuju Tengah dengan variasi kontainer sebanyak 19 jenis (Tabel 2). Hasil survei juga menunjukkan bahwa jumlah kontainer terkontrol/Controllable Container (CC) lebih banyak ditemukan dibanding jumlah kontainer bekas/Disposable Container (DC).

Jumlah kontainer terkontrol yang ditemukan di Kecamatan Topoyo, Tappilina, dan Karossa berturut-turut sebesar 348 buah
(97\%), 363 buah (99\%) dan 52 buah (100\%), sedangkan jumlah kontainer bekas yang ditemukan di Kecamatan Topoyo, Tappilina, dan Karossa berturut-turut sebesar 8 buah (2\%), 2 buah (5\%) dan 2 buah (5\%).

Jumlah kontainer terkontrol yang paling banyak di Kecamatan Topoyo, Tappilina, dan Karossa berturut-turut adalah ember sebanyak 167 buah (48\%), ember sebanyak 187 buah (51\%), dan ember sebanyak 192 buah (49\%).

Keberadaan jentik pada kontainer terkontrol di Kecamatan Topoyo, Tappilina, dan Karossa berturut-turut adalah gumbang/gentong sebanyak 8 buah (57\%), ember sebanyak 27 buah (54\%), dan ember sebanyak 16 buah (31\%). 
Tabel 2. Jenis Kontainer Pada Rumah Tangga di Kabupaten Mamuju Tengah, Provinsi Sulawesi Barat Tahun 2015

\begin{tabular}{|c|c|c|c|c|c|c|c|c|c|}
\hline \multirow{2}{*}{ Kontainer } & \multicolumn{3}{|c|}{ Topoyo } & \multicolumn{3}{|c|}{ Tapilina } & \multicolumn{3}{|c|}{ Karossa } \\
\hline & $\mathbf{N}$ & + & $\%$ & $\mathbf{N}$ & + & $\%$ & $\mathbf{N}$ & + & $\%$ \\
\hline Controllable container & 348 & 48 & 13,8 & 363 & 50 & 13,8 & 394 & 52 & 13,2 \\
\hline Bak Mandi & 18 & 4 & 22,2 & 12 & 3 & 25,0 & 25 & 9 & 36,0 \\
\hline Bak WC & 2 & 0 & $\mathbf{0 , 0}$ & 1 & 0 & $\mathbf{0 , 0}$ & 3 & 2 & 66,7 \\
\hline Bak Penampungan & 1 & 0 & $\mathbf{0 , 0}$ & 1 & 0 & 0,0 & 0 & 0 & $\mathbf{0 , 0}$ \\
\hline Drum & 2 & 2 & 100,0 & 15 & 5 & 33,3 & 11 & 4 & 36,4 \\
\hline Gentong/Gumbang & 14 & 8 & 57,1 & 28 & 7 & 25,0 & 23 & 9 & 39,1 \\
\hline Ember & 167 & 24 & 14,4 & 187 & 27 & 14,4 & 192 & 16 & 8,3 \\
\hline Dispenser & 19 & 6 & 31,6 & 8 & 2 & 25,0 & 22 & 5 & 22,7 \\
\hline Kulkas & 10 & 0 & $\mathbf{0 , 0}$ & 8 & 2 & 25,0 & 9 & 0 & $\mathbf{0 , 0}$ \\
\hline Vas/pot bunga & 0 & 0 & $\mathbf{0 , 0}$ & 1 & 1 & 100,0 & 0 & 0 & 0,0 \\
\hline Loyang/Waskom & 94 & 4 & 4,3 & 57 & 1 & 1,8 & 99 & 6 & 6,1 \\
\hline Jerigen & 1 & 0 & $\mathbf{0 , 0}$ & 25 & 2 & 8,0 & 6 & 0 & $\mathbf{0 , 0}$ \\
\hline Galon & 12 & 0 & $\mathbf{0 , 0}$ & 8 & 0 & 0,0 & 1 & 0 & $\mathbf{0 , 0}$ \\
\hline Sumur & 8 & 0 & $\mathbf{0 , 0}$ & 8 & 0 & $\mathbf{0 , 0}$ & 0 & 0 & $\mathbf{0 , 0}$ \\
\hline Panci & 0 & 0 & $\mathbf{0 , 0}$ & 4 & 0 & 0,0 & 3 & 1 & 33,3 \\
\hline Disposable container & 8 & $\mathbf{0}$ & $\mathbf{0 , 0}$ & 2 & $\mathbf{0}$ & 0,0 & 2 & 0 & 0,0 \\
\hline Ban bekas & 6 & 0 & $\mathbf{0 , 0}$ & 2 & 0 & 0,0 & 1 & 0 & $\mathbf{0 , 0}$ \\
\hline Galon bekas & 1 & 0 & $\mathbf{0 , 0}$ & 0 & 0 & 0,0 & 0 & 0 & $\mathbf{0 , 0}$ \\
\hline Panci bekas & 1 & 0 & $\mathbf{0 , 0}$ & 0 & 0 & 0,0 & 0 & 0 & $\mathbf{0 , 0}$ \\
\hline Bak bekas & 0 & 0 & $\mathbf{0 , 0}$ & 0 & 0 & 0,0 & 1 & 0 & $\mathbf{0 , 0}$ \\
\hline $\begin{array}{l}\text { Under controllable } \\
\text { container }\end{array}$ & 1 & 1 & 100,0 & $\mathbf{0}$ & $\mathbf{0}$ & $\mathbf{0 , 0}$ & 2 & $\mathbf{0}$ & $\mathbf{0 , 0}$ \\
\hline Kolam & 1 & 1 & 100,0 & 0 & 0 & 0,0 & 2 & 0 & $\mathbf{0 , 0}$ \\
\hline
\end{tabular}

Indeks Maya

Status indeks maya didasarkan pada kebersihan lingkungan (HRI) dan tempat yang berpotensi sebagai tempat perkembangbiakan nyamuk (BRI). Analisa indeks maya (Tabel 3) menunjukkan bahwa nilai BRI ketiga kecamatan di Kabupaten Mamuju Tengah sebagian besar berada pada kategori sedang, sedangkan nilai HRI dan MI berada pada kategori rendah.

Tabel 3. Proporsi Rumah Tangga berdasarkan Breeding Risk Index (BRI), Hygiene Risk Index (HRI), dan Indeks Maya (MI) di Kabupaten Mamuju Tengah, Provinsi Sulawesi Barat Tahun 2015

\begin{tabular}{cccccccccc}
\hline & \multicolumn{3}{c}{ Topoyo } & \multicolumn{3}{c}{ Tapilina } & \multicolumn{3}{c}{ Karosa } \\
\cline { 2 - 11 } Kategori & BRI & HRI & MI & BRI & HRI & MI & BRI & HRI & MI \\
& 8 & 100 & 85 & 20 & 100 & 85 & 14 & 100 & 87 \\
Rendah & 77 & 0 & 15 & 62 & 0 & 15 & 73 & 0 & 13 \\
Sedang & 15 & 0 & 0 & 18 & 0 & 0 & 13 & 0 & 0 \\
Tinggi & 100 & 100 & 100 & 100 & 100 & 100 & 100 & 100 & 100 \\
\hline Total & & & & & & & &
\end{tabular}


Kepadatan Larva Aedes aegypti

Indikator entomologi berupa ukuran indeks kepadatan larva Ae. aegypti di satu pemukiman tertentu menjadi bahan pertimbangan penting dalam upaya pengendalian vektor yang efektif. Tabel 4 menunjukkan angka indeks entomologi di Kabupaten Mamuju Tengah Provinsi Sulawesi Barat Tahun 2015.

Tabel 4. Angka Indeks Entomologi di Kabupaten Mamuju Tengah Provinsi Sulawesi Barat Tahun 2015

\begin{tabular}{lccc}
\hline Indeks Entomologi & Topoyo & Tapilina & Karosa \\
\hline House Index & $36 \%$ & $36 \%$ & $38 \%$ \\
Container Index & $15,5 \%$ & $15,8 \%$ & $15 \%$ \\
Breteau Index & 48 & 50 & 52 \\
Density Figure & 5 & 5 & 5 \\
Angka Bebas Jentik & $64 \%$ & $64 \%$ & $62 \%$ \\
\hline
\end{tabular}

\section{PEMBAHASAN}

Hasil penelitian di Kabupaten Mamuju Tengah pada tahun 2015 masih ditemukan kontainer berisi jentik di rumah tangga. Namun, hasil penelitian ini merupakan kejadian lama yang saat ini pasti berubah. Keberadaan jentik berkaitan dengan jenis, letak dan jumlah kontainer yang ada dalam rumah tersebut. Jenis kontainer dominan yang ditemukan dan merupakan tempat perkembangbiakan Ae. aegypti adalah ember, tempayang/gentong, bak mandi, dan dispenser. ${ }^{14-16}$ Hasil penelitian ini sejalan dengan penelitian Ambarita yang menemukan bahwa kontainer yang paling dominan ditemukan jentik adalah bak mandi, ember, dan drum. Hal yang sama juga ditemukan pada penelitian Prasetyowati, menyebutkan bahwa kontainer yang paling dominan adalah ember dan dispenser. ${ }^{7,12}$ Ember merupakan kontainer yang paling banyak dijumpai di rumah tangga kasus. Masyarakat cenderung menggunakan ember sebagai pengganti bak mandi dengan alasan kepraktisan dan tidak membutuhkan tempat yang luas. Selain itu, masyarakat juga menggunakan ember untuk menyimpan air dalam jumlah banyak sebagai cadangan mana kala persediaan air terbatas Kebiasaan masyarakat menampung air untuk keperluan sehari-hari memberi peluang bagi Aedes aegypti untuk berkembangbiak pada tempat tersebut. Penelitian di Jakarta menemukan bahwa jenis kontainer positif mempunyai hubungan dengan keberadaan jentik. Prasetyowati tahun 2018 mengungkapkan resiko terkena DBD pada masyarakat yang mempunyai kontainer jenis ember. Penggunaan ember sebagai penampung air seharusnya memudahkan dalam mengontrol keberadan jentik, namun pada faktanya ember justru menjadi kontainer dominan yang berperan dalam keberadaan larva. ${ }^{12}$

Keberadaan dispenser yang ditemukan jentik, juga perlu menjadi perhatian tersendiri. Dispenser merupakan tempat penampungan air minum yang digunakan sehari-hari. Struktur dispenser dapat menampung adanya tumpahan air minum dalam wadah penampung yang tidak tertutup rapat. Adanya penutup yang tidak rapat dalam wadah penampung air tersebut menjadikan Ae. aegypti dapat berkembangbiak didalamnya. Beberapa rumah tangga meletakkan dispenser di pojok-pojok ruangan dengan intensitas cahaya matahari kurang dan kelembabannya tinggi sehingga sangat mendukung untuk tempat perkembangbiakan Ae. aegypti. ${ }^{12}$ Menurut Purnama dan Baskoro salah satu penyebab adanya jentik pada dispenser adalah karena penampungan air di dispenser yang seringkali secara tidak sengaja menampung air sisa dari kran, letaknya tersembunyi, sehingga jarang 
terlihat dan terlupakan. Hasil penelitian pada tahun 2015 menunjukkan tidak ada data yang menjelaskan apakah responden tidak tahu bahwa wadah tersebut dapat menjadi tempat perkembangbiakan Ae. aegypti atau responden lalai membersihkan tempat penampungan tersebut sehingga dispenser memiliki proporsi tertinggi kontainer yang ditemukan jentik..$^{17,18}$

Kurangnya kesadaran masyarakat dalam membersihkan kontainer yang berada di dalam rumah maupun di luar rumahnya, sehingga sangat efektif sebagai tempat perkembangbiakan nyamuk Ae. aegypti. Perilaku sebagian besar masyarakat yang tidak didasari akan kesadaran pentingnya memelihara kebersihan lingkungan serta kurang baiknya tindakan masyarakat dalam melaksanakan PSN DBD akan menciptakan lingkungan yang kondusif bagi perkembangbiakan Ae. aegypti. ${ }^{19}$

Banyaknya kontainer terkendali yang ditemukan di dalam rumah terlihat pada hasil BRI. Nilai BRI pada rumah tangga di tiga Kecamatan Topoyo, Tappilina dan Karossa sebagian besar pada kategori sedang. Hasil ini menunjukkan bahwa banyak ditemukan $\mathrm{CC}$ di masyarakat yang mempunyai risiko lebih besar sebagai tempat berkembangbiak larva $A e$. aegypti. Hasil serupa juga didapatkan pada penelitian di Tegalsari, nilai BRI sebagian besar pada kategori sedang. Dengan kondisi seperti ini potensi penularan DBD di rumah tangga tersebut lebih besar karena banyak kontainer yang terkendali positif jentik. ${ }^{12,20}$

Kontainer bekas yang ditemukan sebagian besar adalah aquarium, bak bekas, ban bekas, panci bekas dan galon bekas yang banyak ditemukan di luar rumah dengan kondisi yang tidak terurus dan sudah tidak digunakan oleh rumah tangga. Disposable container (DC) merupakan indikator sebagai indeks HRI yaitu aspek kebersihan lingkungan sekitar rumah dimana nilai HRI di rumah tangga di kacamatan Topoyo, Tappilina dan Karossa termasuk kategori rendah. Hasil ini serupa dengan hasil penelitian di Dusun Tegalrejo dan Dusun Krajan Kidul nilai HRI berada pada kategori rendah. Rendahnya nilai
HRI menunjukkan bahwa kebersihan lingkungan masih relatif bersih, namun sebaliknya pada nilai HRI yang tinggi menunjukkan bahwa rumah atau pemukiman tersebut semakin kotor. $^{21}$ Toan dalam Prasetyowati menyatakan bahwa rumah yang tidak higienis berpeluang 3,4 kali terjadi penularan DBD. ${ }^{12}$

Status indeks maya didasarkan pada kebersihan lingkungan (HRI) dan tempat yang berpotensi sebagai tempat perkembangbiakan nyamuk (BRI). Analisis indeks maya, menunjukkan bahwa nilai BRI di Kabupaten Mamuju Tengah sebagian besar berada pada kategori sedang. Sedangkan nilai HRI dan MI untuk ketiga kecamatan tersebut umumnya berada pada kategori rendah namun bukan berarti bebas dari DBD. Keberadaan kontainer positif pada daerah dengan indeks maya kategori rendah sampai sedang masih menunjukkan daerah tersebut potensial untuk terjadinya penularan. Hal ini sejalan dengan penelitian di Provinsi Lampung yang juga mendapatkan indeks maya dengan kategori rendah sampai sedang. ${ }^{21}$

Analisis kepadatan larva Ae. aegypti di Kecamatan Topoyo, termasuk kategori sedang dengan nilai HI sebesar $36 \%$, CI sebesar $15,5 \%$ dan BI sebesar 48. Nilai ABJ menunjukkan angka $64 \%$ yang masih jauh dari ABJ standar yaitu 95\%. Sedangkan di Kecamatan Tappilina dan Kecamatan Karossa termasuk kategori tinggi dengan nilai $\mathrm{HI}$ sebesar $36 \%$ dan $38 \%$, nilai CI sebesar $15,8 \%$ dan $15 \%$, dan nilai BI sebesar 50 dan 52. Nilai ABJ kedua kecamatan ini menunjukkan nilai 64\% dan 62\%. Menurut Focks dalam Pahlepi et al, berdasarkan kategori WHO, apabila nilai $\mathrm{HI}<1 \%$ maka daerah berisiko rendah sedangkan apabila nilai $\mathrm{HI}$ dan $\mathrm{CI}>5 \%$ dan $\mathrm{BI}>50$ maka daerah tersebut memiliki risiko tinggi. Semakin tinggi nilai HI maka semakin tinggi pula kepadatan nyamuk dan semakin tinggi juga risiko penularan penyakit DBD. ${ }^{22,23}$ Demikian juga nilai $\mathrm{ABJ}$, meskipun masih kurang dari 95\% hal ini dapat menyebabkan terjadinya transmisi virus DBD. 


\section{KESIMPULAN}

Indeks maya di Kabupaten Mamuju Tengah berada pada kategori rendah, meskipun demikian berdasarkan indeks entomologi masih ditemukan kontainer positif larva sehingga potensi terjadinya penularan DBD masih tetap ada.

\section{SARAN}

Perlu dilakukan survei jentik secara berkala dan pemberantasan jentik dengan larvasida massal serta penyuluhan pada masyarakat akan pentingnya pelaksanaan 3M dan menggalakkan Pemberantasan Sarang Nyamuk (PSN).

\section{KONTRIBUSI PENULIS}

Kontribusi setiap penulis dalam artikel ini adalah M, HM dan MM sebagai kontributor utama bertanggung jawab dalam konsep penulisan artikel secara menyeluruh. $\mathrm{N}$ dan $\mathrm{R}$ sebagai kontributor anggota bertanggung jawab dalam analisis dan penyajian data.

\section{UCAPAN TERIMA KASIH}

Pada kesempatan ini penulis mengucapkan terima kasih kepada Kepala Badan Penelitian dan Pengembangan Kesehatan yang telah mendanai penelitian ini, Kepala Pusat Teknologi Intervensi Kesehatan, Kepala Balai Litbangkes Donggala, Kepala Dinas Kesehatan Provinsi Sulawesi Barat, Kepala Dinas Kesehatan Kabupaten Mamuju Utara, Kepala Dinas Mamuju Tengah, Kepala Dinas Kabupaten Polewali Mandar, Pengelola Program DBD, atas ijin, bantuan dan kerja samanya selama pelaksanaan penelitian ini berlangsung.

\section{DAFTAR PUSTAKA}

1. Santoso S, Margarety I, Taviv Y, Wempi IG, Mayasari R, Marini M. Hubungan karakteristik kontainer dengan keberadaan jentik Aedes aegypti pada kejadian luar biasa Demam Berdarah Dengue: studi kasus di Kabupaten Ogan Komering Ulu. J Vektor Penyakit. 2018;12(1):9-18. doi:10.22435/vektorp.v12i1.229.
2. Ridha M, Sembiring W, Fadily A, Sulasmi S. Indikator entomologi dan status resistensi vektor Demam Berdarah Dengue (Aedes aegypti L) terhadap beberapa golongan insektisida di Kota Banjarbaru. Prosiding Seminar Nasional Seri 8; 2018 September 27. Yogyakarta: UII; 2018.p 128-42.

3. WHO. Comprehensive guidelines for prevention and control of dengue and dengue haemorrhagic fever. India: WHO Regional Publication SEARO; 2011.

4. Maksud M, Udin Y, Mustafa H, Risti, Jastal. Survei jentik DBD di Tempat-tempat Umum (TTU) di Kecamatan Tanantovea, Kabupaten Donggala, Sulawesi Tengah. J Vektor Penyakit. 2015;9(1):9-14. doi:10.22435/vektorp.v9i1.5039.9-14.

5. Agustin I, Tarwotjo U, Rahardian R. Perilaku bertelur dan siklus hidup Aedes aegypti pada berbagai media air. J Akad Biol. 2017;6(4):7181.

6. Riandi MU, Hadi UK, Soviana S. Karakteristik habitat dan keberadaan larva Aedes spp. pada wilayah kasus Demam Berdarah Dengue tertinggi dan terendah di Kota Tasikmalaya. ASPIRATOR. 2017;9(1):43-50.

7. Ambarita LP, Sitorus H, Komaria RH. Habitat Aedes pradewasa dan indeks entomologi di 11 Kabupaten/Kota Provinsi Sumatera Selatan. BALABA. 2016;12(2):111-20. doi:10.22435/blb.v12i2.222.

8. Dinas Kesehatan Kabupaten Mamuju Tengah. Profil Kesehatan Kabupaten Mamuju Tengah Tahun 2016. Mamuju Tengah: Dinkes Kab Mamuju Tengah; 2017. 120p.

9. Maksud M, Mustafa H, Risti, Nelfita, Murni, Jastal. Aktifitas penggunaan insektisida komersil oleh masyarakat di daerah endemis Demam Berdarah Dengue di Provinsi Sulawesi Barat. J Vektor Penyakit. 2019;13(1):59-65. doi:10.22435/vektorp.v13i1.964.

10. Jastal, Udin Y, Mustafa H, Maksud M, Kuniawan A, Risti, Srikandi Y. Pemetaan status kerentanan Aedes aegypti terhadap insektisida di Indonesia 2015 (studi di lima provinsi di Sulawesi) [Laporan Penelitian]. Donggala: Balai Litbangkes Donggala; 2015.

11. Heeringa SG, Wagner J, Torres M, Duan N, Adams T, Berglund P. Sample designs and sampling methods for the Collaborative Psychiatric Epidemiololgy Studies (CPES). Int 
J Methods Psychiatr Res. 2004;13(4):221-40. doi: 10.1002/mpr.179.

12. Prasetyowati H, Astuti EP, Hendri J, Fuadzy H. Risiko penularan DBD berdasarkan maya index dan key container pada rumah tangga kasus dan kontrol di Kota Bandung. BALABA. 2018;14(2):181-90. doi:10.22435/blb.v14i2.399.

13. Dirjen Pengendalian Penyakit dan Penyehatan Lingkungan. Pedoman survei entomologi Demam Berdarah Dengue dan kunci identifikasi nyamuk. Jakarta: Dirjen P2PL; 2013.

14. Agustina N, Abdullah A, Arianto E. Hubungan kondisi lingkungan dengan keberadaan jentik Aedes aegypti di daerah endemis DBD di Kota Banjarbaru. BALABA. 2019;15(2):171-8. doi:10.22435/blb.v15i2.1592.

15. Nurjana MA, Kurniawan A. Preferensi Aedes aegypti meletakkan telur pada berbagai warna ovitrap di laboratorium. BALABA. 2017;13(1):37-42. doi:10.22435/blb.v13i1.256.

16. Tomia A, Hadi UK, Soviana S, Retnani EB. Maya index dan kepadatan larva Aedes aegypti di Kota Ternate, Maluku Utara. BALABA. 2019;15(2):133-42. doi:10.22435/blb.v15i2.1936.

17. Purnama SG, Baskoro T. Maya index and larva density Aedes Aegypti toward dengue infection. Makara. 2012;16(2):57-64. doi:10.7454/msk.v16i2.1630.
18. Alim L, Heriyani F, Istiana I. Tingkat kepadatan jentik nyamuk Aedes aegypti pada tempat penampungan air controllable sites dan disposable sites di sekolah dasar Kecamatan Banjarbaru Utara. Berk Kedokt. 2017;13(1):714. doi:10.20527/jbk.v13i1.3434.

19. Narmala YA, Azizah R. Maya index dan kepadatan larva Aedes aegypti antara dusun Tegalrejo dan Dusun Krajan Kidul Nanggungan Pacitan. The Indonesian Journal of Public Health. 2019;14(2):199-209. doi:10.20473/ijph.v14i2.2019.199-209.

20. Rokhmawanti N, Ginanadjar P, Martini M. Hubungan maya index dengan kejadian Demam Berdarah Dengue di Kelurahan Tegalsari Kota Tegal. J Kesehat Masy. 2015;3(1):162-70.

21. Sona B, Rosa E, Kanedi M, Tugiyono. Maya index analysis of dengue fever vector in East Metro Sub-District Lampung Province Indonesia. J Ilm Biol Ekperimen dan Keanekaragaman Hayati. 2019;6(1):1-7.

22. Taslisia T, Rusdji SR, Hasmiwati H. Survei entomologi, maya indeks, dan status kerentanan larva nyamuk Aedes aegypti terhadap temephos. J Kesehat Andalas. 2018;7(1):33-41. doi:10.25077/jka.v7i1.777.

23. Pahlepi RI, Soviana S, Retnani EB. Kepadatan dan karakteristik habitat larva Aedes spp. di sekolah dasar daerah endemis DBD Kota Palembang. Spirakel. 2017;9(2):68-78. 
BALABA Vol. 16 No. 2, Desember 2020: 189-198 